\title{
Posouzení efektivity navržených opatření v ploše povodí hydrologickým modelem
}

\section{KAMILA OSIČKOVÁ, JANA UHROVÁ}

Klíčová slova: povodí Litavy - srážko-odtokový model - hydrologický model - schematizace plošná ochranná opatření - liniová biotechnická ochranná opatření - HEC-HMS

\section{SOUHRN}

Príspěvek prezentuje část výstupů čtyřletého projektu Nové postupy optimalizace systémů integrované ochrany území v kontextu jejich ekonomické udržitelnosti. Jeho cílem je posouzení efektivnosti komplexního systému opatření navržených v ploše části povodí Litavy $\left(136,85 \mathrm{~km}^{2}\right)$ s použitím hydrologického modelu, vytvořeného v programu HEC-HMS (Hydrology Engineering center Hydrologic modeling system) [1]. Hodnocení efektivnosti bylo provedeno díky simulaci s aplikací čtyř prívalových srážkových epizod. Pro stanovení a výpočet hydrologických ztrát a transformace v modelu byla zvolena metoda SCS CN. Návrhy biotechnických liniových opatření ovlivnily vstupní schematizaci povodí a v prípadě bezodtokých opatření byla stanovena jejich retenční kapacita.

\section{ÚVOD}

Realizací komplexní ochrany a organizace povodí je možno výrazně zvýšit retenční schopnost povodí, obzvláště infiltraci srážkové vody do půdy a zadržení a postupné zasáknutí části povrchového odtoku v ploše povodí. Komplex ochranných opatření v ploše povodí plní v krajině řadu funkcí (protierozní, protipovodňovou, ochranu před suchem, ale i ekologickou) podporujících ochranu krajinných systémů. V dnešní době je jedním z hlavních způsobů jak provést analytické vyhodnocení hydrologie povodí hydrologické modelování. Modelování obecně představuje zjednodušený popis reality, který slouží k lepšímu pochopení modelovaného systému a k předpovědi jeho chování [2].

Cílem př́spěvku je posouzení efektivnosti komplexního systému opatření navržených v ploše části povodí Litavy s použitím hydrologického modelu, vytvořeného v programu HEC-HMS (Hydrology Engineering center - Hydrologic modeling system) [1]. Hodnocení efektivnosti bylo provedeno díky simulaci s aplikací čtyř prívalových srážkových epizod.

Pro vyhodnocení byla vybrána východní topograficky velmi členitá, zemědělsky využívaná část povodí Litavy, a to z důvodu velkého počtu lokalit mimorádně silně ohrožovaných nebezpečnými odtoky z prívalových srážek, které vedou k četným povodňovým situacím, doprovázených intenzivní vodní erozí a transportem splavenin. Ty mají zásadní vliv na ekologickou nestabilitu některých ploch.

\section{MATERIÁLY A METODA HODNOCENÍ EFEKTIVITY OPATŘENÍ}

Základem při posouzení efektivity opatření bylo vytvoření hydrologického srážko-odtokového (S-O) modelu, v němž byl následně modelován vliv navržených opatření na velikost kulminačního průtoku a objemu povrchového odtoku. K jeho vytvoření bylo třeba stanovit orientační specifické odtoky, tedy průtok vztažený na jednotku plochy za určitý časový úsek, které s růstem plochy povodí klesají, a objemové průtoky pro zájmový nemonitorovaný závěrový profil povodí $\checkmark$ katastru obce Bučovice (o ploše povodí 136,86 km²). Získané hodnoty byly stanoveny ze sestaveného zjednodušeného modelu povodí Litavy (obr. 1) s označením míst s dlouhodobým měřením průtoků ve stanicích Brankovice (hlásný profil ČHMÚ č. 381 o ploše povodí 71,79 km²) a Rychmanov (hlásný profil ČHMú č. 382 o ploše povodí 495,38 km²) [3]. Výpočet specifických odtoků pro jednotlivé stanice a čtyři vybrané povodňové epizody vycházel z ploch povodí a objemů povrchových odtoků, získaných z reálných naměřených dat z těchto stanic. Závěrový profil zájmové oblasti se pak nachází mezi těmito dvěma stanicemi, tzn., že hodnoty vypočítaného objemu povrchového odtoku i hodnota specifického odtoku se nacházejí v intervalu hodnot těchto parametrů mezi měrnými stanicemi.

Vypočítané specifické odtoky se pohybovaly v rozmezí 4,4-13,6 I/s/ $\mathrm{km}^{2}$ pro profil Brankovice, 3,0-9,3l/s/ $\mathrm{km}^{2}$ pro profil Rychmanov a $4,1-12,9 \mathrm{l} / \mathrm{s} / \mathrm{km}^{2}$ pro zájmový profil Bučovice.

\section{TVORBA SRÁŽKO-ODTOKOVÉHO MODELU}

Pro rešené území části povodí Litavy bylo nutné vytvoření S-O modelu ve dvou krocích. Nejdřive byl vytvořen S-O model se závěrovým profilem Brankovice, kde probíhá kontinuální měření. Zde byla provedena podrobná kalibrace a parametry tohoto modelu byly následně aplikovány do modelu se závěrovým profilem Rychmanov, který byl pro kalibraci rozdělen do šesti kalibračních částí (obr. 2), které mají rozdílné kalibrační koeficienty. Koeficienty v horní části povodí byly stanoveny právě v prvním modelu. Cílem tohoto rozdělení bylo zachytit rozdílnost chování rưzných částí (dílčích povodí př́toků) povodí Litavy. Prvním nezbytným krokem pro vytvoření S-O modelu řešeného území je schematizace povodí, tj. rozdělení na dílči povodí, z nichž každé má své specifické vlastnosti. V zájmovém území povodí Litavy byla provedena podrobná schematizace se zohledněním návrhů biotechnických opatření. Pro část povodí $\checkmark$ úseku Bučovice-Rychmanov byla provedena schematizace hrubšího charakteru. Ve schematizaci části povodí po profil Brankovice bylo povodí rozděleno na 42 subpovodí, po profil Bučovice bylo vytvořeno 90 subpovodí a v povodí po profil Rychmanov bylo vymezeno 114 subpovodí (obr. 1). 


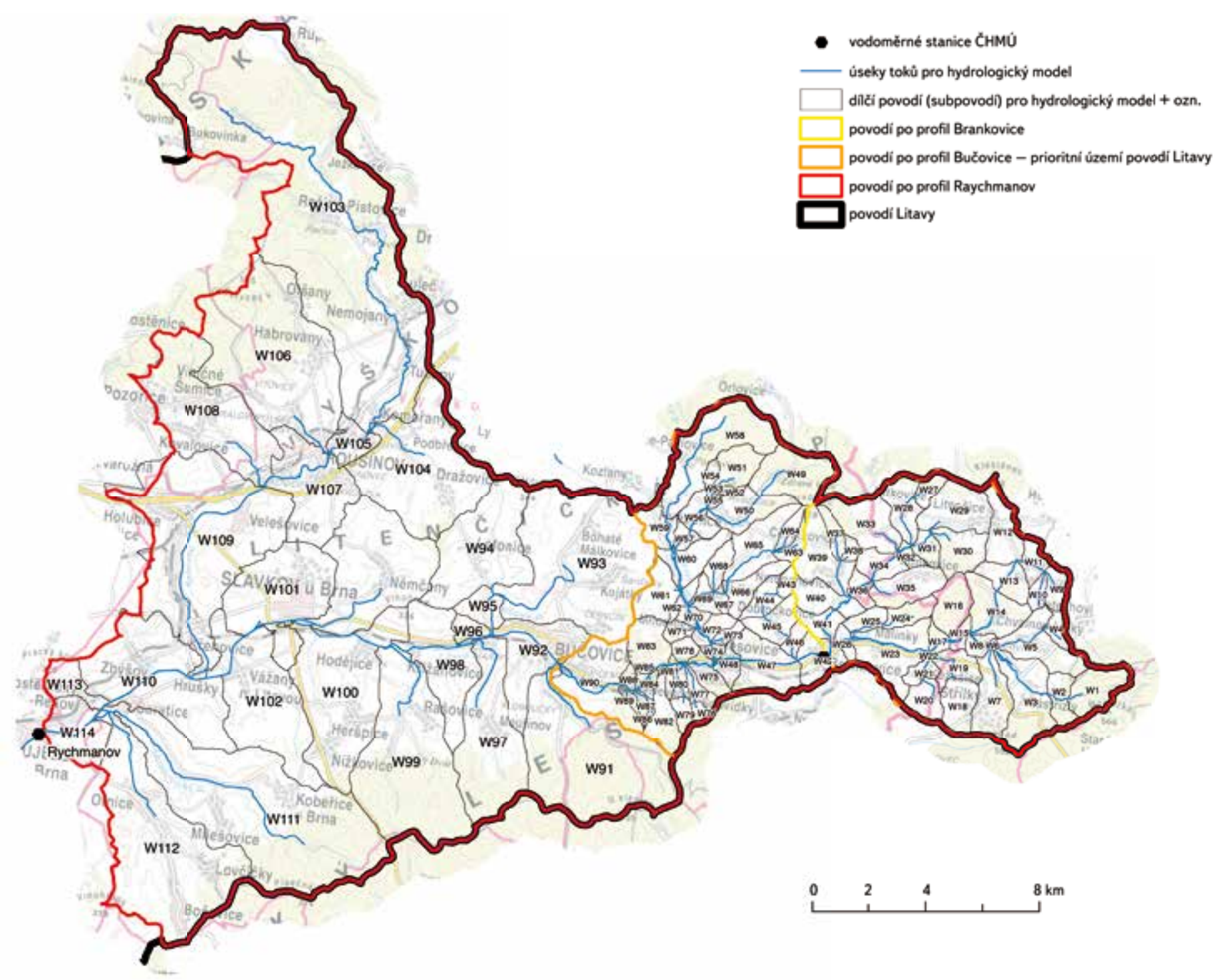

Obr. 1. Schematizace pro HEC-HMS

Fig. 1. Schematization to HEC-HMS

Do programu HEC-HMS vstupuje schematizované povodí, tj. úseky a jejich charakteristiky (délky, průměrné sklony, rozměry, drsnosti) a $k$ nim zavěšené plochy a jejich charakteristiky (plocha, sklon aj.) podle zvolených výpočtových metod. Pro naše podmínky byla pro výpočet hydrologických ztrát a transformace zvolena metoda SCS CN. Pro transformaci prímého odtoku byl využit jednotkový hydrogram podle Clarka (Clark unit hydrograph), pro výpočet podzemního odtoku byla využita recesní metoda (recession) a odtok $v$ korytě byl stanoven s využitím metody Muskingum-Cunge, která je založena na aproximaci kombinace rovnice kontinuity a difúzní formy momentové rovnice [4] a podrobněji je popsána např. Feldmanem [5].

Kalibrace modelu (obr. 3) při současném využití krajiny proběhla na vybrané reálné povodňové epizodě z roku 2014 (3.-8. 8. 2014), kdy dosáhla kulminace $\checkmark$ profilu Brankovice $4,76 \mathrm{~m}^{3} / \mathrm{s}$ a $v$ profilu Rychmanov $9,35 \mathrm{~m}^{3} / \mathrm{s}$ a celkový úhrn srážek ve srážkoměrné stanici Nemochovice byl $67,3 \mathrm{~mm}$. Hlavními ukazateli úspěšnosti kalibrace modelu jsou Nash-Suttleffe kritérium shody (shoda je dostatečná, pokud E $\geq 0$,5) [6] a objem povrchového odtoku W (model je považován za príijatelný, pokud rozdíl modelovaného povrchového odtoku a požadovaného objemového odtoku nepřekročil 10 \%). Hodnoticí kritéria kalibrace modelu jsou následující:
- $\mathrm{E}=0,939, \Delta \mathrm{W}=+6,02 \%$ (Brankovice), $\Delta \mathrm{W}=+0,06 \%$ (Bučovice), $\Delta \mathrm{W}=+3,63 \%$ (Rychmanov).

Verifikace modelu pak proběhla na dalších třech reálných povodňových epizodách, které byly vyvolány př́valovými srážkami:

- 12.-17. 6. 2012: $E=0,906 ; \Delta W=+0,07 \%$ (Brankovice), $\Delta W=+0,20 \%$ (Bučovice), $\Delta \mathrm{W}=+7,16 \%$ (Rychmanov),

- 11.-20. 9. 2014: $E=0,706 ; \Delta W=+0,40 \%$ (Brankovice), $\Delta W=-0,16 \%$ (Bučovice), $\Delta \mathrm{W}=-6,77 \%$ (Rychmanov),

- 1.-5. 10. 2014: $E=0,893 ; \Delta W=-0,85 \%$ (Brankovice), $\Delta W=+0,22 \%$ (Bučovice), $\Delta \mathrm{W}=-7,50 \%$ (Rychmanov).

Větší rozdílnost povrchových objemů v profilu Rychmanov je dána predevším hrubší schematizací a menší podrobností srážkových dat. Data z profilu Rychmanov sloužila zejména k ověření správnosti modelu a stanovení objemových průtoků $v$ závěrovém profilu zájmové oblasti. Rozdíl modelovaných objemů však ani v profilu Rychmanov není větší či menší než $10 \%$. Model byl tedy vyhodnocen jako dostatečně přesný a použitelný pro další účely. 


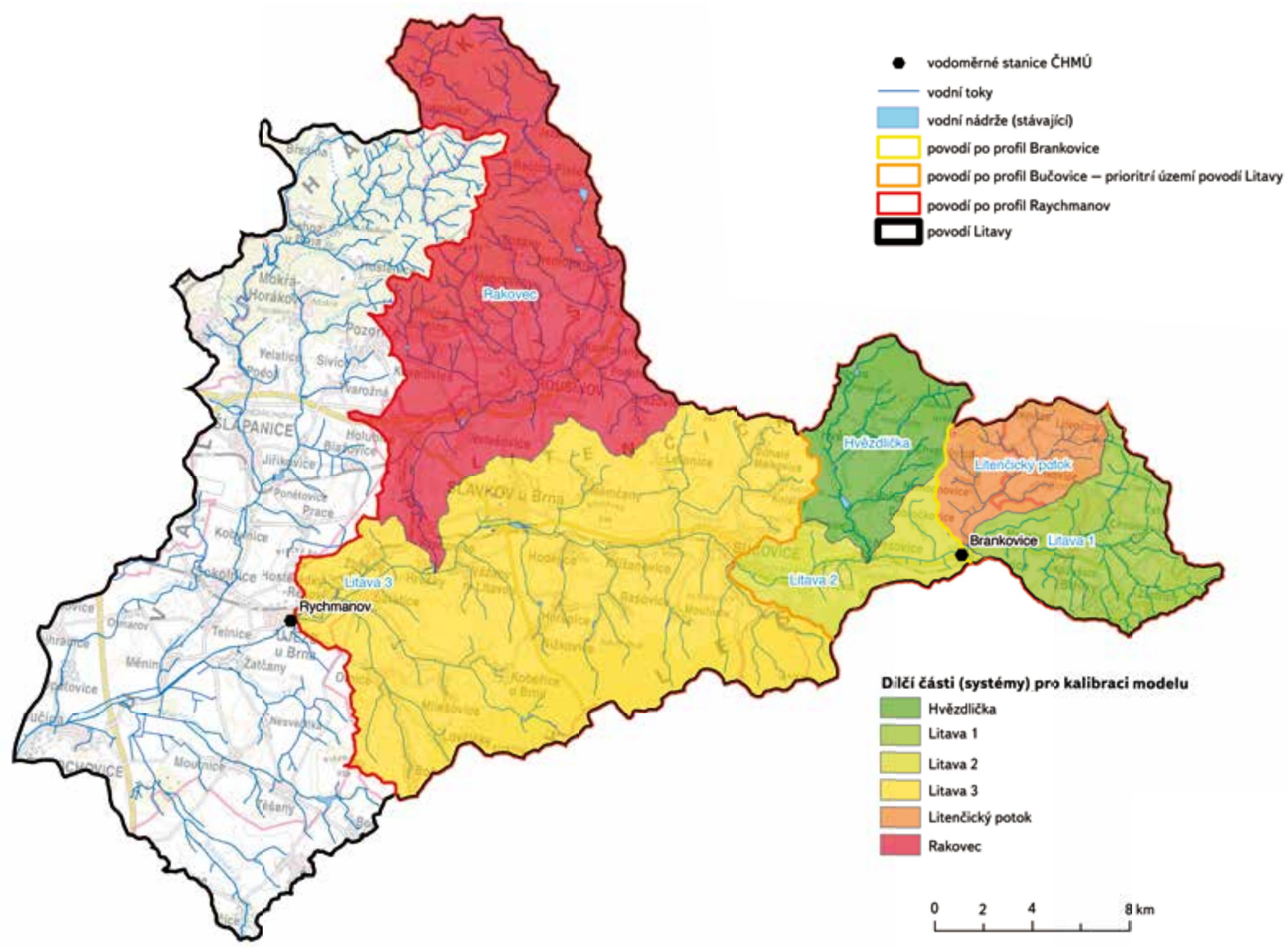

Obr. 2. Kalibrační systémy povodí Litavy

Fig. 2. Calibration systems od Litava basin

\section{NÁVRHY OPATŘENÍ V PLOŠE POVODÍ}

Návrhy opatření v ploše povodí byly vyhotoveny podle běžných postupů realizujících se v návrzích plánů společných zařízení v rámci pozemkových úprav. Celková plocha zemědělské půdy v zájmovém povodí činí $81,262 \mathrm{~km}^{2}$, tedy zhruba 59,38 \% a plocha samotné orné půdy $77,625 \mathrm{~km}^{2}$, tedy zhruba $56,72 \%$. Na této ploše došlo k vytvoření expertního návrhu plošných a liniových ochranných opatření na blocích zemědělsky využívané půdy evidované $v$ registru LPIS $\checkmark$ celém řešeném povodí. Plochy vedené jako zatravněné do návrhu již nevstupovaly. Navrhováno bylo několik typů plošných opatření. Agrotechnická opatření (AGT) mírnější (výsevu do ochranné plodiny, strniště, mulče nebo posklizňových zbytků), intenzivnější AGT (kdy se kukuřice zásadně seje vrstevnicově do krycí plodiny (např. do vymrzlé svazenky), obiloviny a řepka se sejí také vrstevnicově a v osevním postupu je také větší zastoupení ozimých obilovin, luskovin a víceletých pícnin). Ochranné sady a vinice mají zatravněná meziřadí a jsou situovány ve směru vrstevnic. Opatření formou vyloučení erozně nebezpečných plodin z osevní rotace nebo jeho intenzivnější forma, kdy vedle vyloučení kukuřice, slunečnice a řepky se vrstevnicově sejí také obiloviny a v osevním postupu je větší zastoupení ozimých obilovin, luskovin a víceletých pícnin.
Výskyt plošných ochranných opatření na zemědělské půdě je závislý na způsobu využití půdy v jednotlivých katastrech. Návrh plošných opatření zaujímá 93,91 \% ploch orné půdy, výměry jednotlivých druhů opatření uvádí tabulka 1.

Návrh byl dále zaměřen na návrh liniových ochranných opatření typu zasakovací mez, zasakovací pás a dráha soustředěného odtoku. Při lokalizaci liniových opatření byl brán v potaz návrh prvků ÚSES. Docházelo ke sloučení těchto krajinotvorných, ochranných prvků tak, aby byla dodržena jejich funkčnost. Lokalizace jednotlivých typů opatření je znázorněna na obr. 4. Jejich počty a součty délek uvádí tabulka 2, u všech opatření byla použita šířka $30 \mathrm{~m}$.

Návrh prošel řadou vývojových stádií a řadou úprav ovlivněných stávajícími prvky v krajině, návrhy vedenými v územně plánovací dokumentaci a v ukončených pozemkových úpravách, terénním šetřením, opakovaným vyhodnocením účinnosti ochrany a projednáním s uživateli i vlastníky půdy a zástupci dotčených obcí. Vznikl tak návrh ochranných opatření ve smyslu návrhů realizovaných $\vee$ procesech pozemkových úprav, který nahlízí na celé zájmové povodí jako na hydrologicky uzavřený celek. 


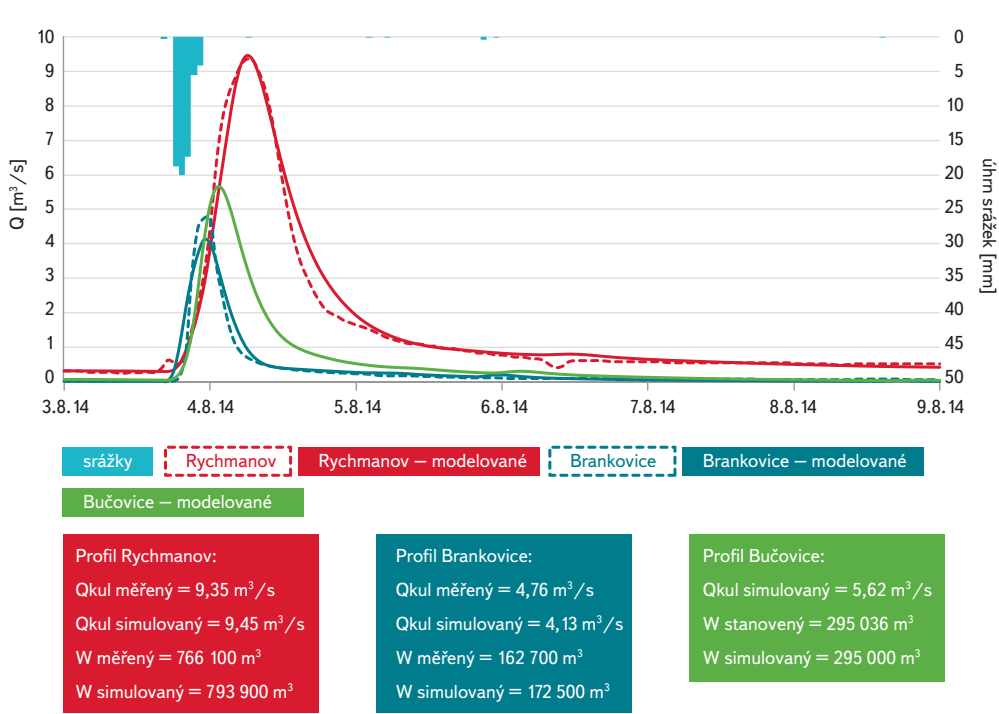

Obr. 3. Kalibrace S-O modelu

Fig. 3. Calibration of precipitation-runoff model (red/dashed red - profile Rychmanov simulated/observed, blue/dashed blue - Brankovice simulated/observed

green - Bučovice simulated, no observed data)

\section{SCHEMATIZACE OPATŘENÍ V S-O MODELU}

Efektivitu těchto opatření Ize stanovit např́klad jejich promítnutím do hydrologického S-O modelu. Je však složité schematizovat všechny typy opatření $\checkmark$ modelu tak, aby jejich modelovaný vliv odpovídal co nejvíce realitě a nebyly opomenuty hlavní účinky jednotlivých typů opatření.

Plošná organizační či agrotechnická opatření, stejně jako zasakovací pásy či zatravněné údolnice a meze i př́kopy, byly do modelu promítnuty změnou pokryvu, tedy změnou (snížením) čísla CN. Jde o metodu hojně užívanou a dostatečně vypovídající.

Pro znázornění vlivu čísla CN na velikost kulminačního průtoku i povrchového odtoku byla provedena analýza na dvou vybraných subpovodích, které jsou z větší části tvořeny ornou půdou. Pro tuto analýzu byla vybrána subpovodí W43 (obr. 1) - malé povodí $(0,49$ km²) s vysokým průměrným sklonem (23,97 \%) a podílem orné půdy $98,31 \%$ a subpovodí W61 - větší povodí $(2,28$ km²) s mírnějším průměrným sklonem (5,15\%) a podílem orné půdy $96,43 \%$. Výsledkem této analýzy byl graf závislosti čísla $C N$ na $Q_{k u l}$ a W, z něhož vyplývá, že závislost obou veličin má pro jednotlivé povodí obdobný nebo téměř shodný polynomický průběh (obr.5).

Tabulka 1. Výměry plošných ochranných opatřenív zájmovém povodí

Table 1. Size of the area erosion control measures in the basin

\begin{tabular}{lc} 
Typ opatření & Plocha [ha] \\
\hline agrotechnická (AGT) mírnější & 3324,066 \\
\hline agrotechnická (AGT) přísnější & 648,858 \\
\hline ochranné sady a vinice & 265,616 \\
\hline trvalé zatravnění & 1294,351 \\
\hline vyloučení erozně nebezpečných plodin & 389,595 \\
\hline vyloučení erozně nebezpečných s AGT & 1366,968 \\
\hline interakční prvek & 1,497 \\
\hline
\end{tabular}

Celkem

7289,454

\section{VÝSLEDKY A DISKUSE}

\section{Vliv a efektivita opatření}

Na verifikovaném hydrologickém modelu byly provedeny simulace př́znivého scénáře využití území, včetně navrhovaných liniových opatření, pro všechny čtyři modelované epizody (obr. 6-9), které byly způsobeny př́valovými srážkami.

Jak již bylo zmíněno výše, změna využití území a navrhovaných opatření byla do modelu promítnuta změnou čísla $C N$ v dílčích povodích, které se v průměru snížilo o téměř 6 \% (maximálně o 11,25 \%).

Zjištěný vliv navržených opatření na velikost kulminačního průtoku i objemu povrchového odtoku $v$ závěrovém profilu zájmového povodí není zanedbatelný a je uveden $v$ tabulce 3. Aplikací navrhovaného scénáře do vytvořeného modelu došlo $v$ závěrovém profilu Bučovice ke snižení kulminačních průtoků o 4,8 \% (E1), 5,3 \% (E2), 18,4 \% (E3), 17,2 \% (E4) a snížení objemu povrchového odtoku o 11,5 \% (E1), 5,29 \% (E2), 16,2% (E3), 16,35 \% (E4). Míra snížení sledovaných veličin je tedy přímo úměrná velikosti původní povodňové epizody. Procentuální změna odtoku odpovídá zatížení srážek s vysokými úhrny za krátký časový interval.

I pokud by biotechnická opatření (príkopy, průlehy, meze apod.) vstupovala do modelu ne ve formě změny čísla $C N$, ale jako nekonečně malá vodní nádrž bez funkčních objektů, což model HEC-HMS umožňuje, byl by vzhledem k jejich malé rozloze jejich význam pro hodnocení snížení povrchového odtoku v závěrovém profilu povodí téměř nulový. Celková kapacita navržených zasakovacích prvků byla stanovena na zhruba 10 tis. $\mathrm{m}^{3}$ při uvažovaných modelových parametrech (širrka ve dně $=0,4 \mathrm{~m}$, hloubka $=0,5 \mathrm{~m}$, sklony svahů $=1: 2$ ).

Pracujeme však s myšlenkou dalšího výzkumu s použitím komponenty vodní nádrže "reservoir" pro modelování vlivu zasakovacích bezodtokových navrhovaných liniových prvků, právě jako nekonečně malé nádrže bez funkčních objektů. Problematice vyhodnocení liniových opatření se v poslední době u nás věnovali již publikované práce např. Feltl [7] a Strouhal [8]. Každé jednotlivé opatření je však třeba posoudit individuálně a stanovit přesné parametry jednotlivých opatření s ohledem na morfologii terénu a lokální podmínky. Tento postup je ale u rozsáhlejších území zdlouhavý, a proto bude cílem následného zpracování i zjednodušení efektivního návrhu liniových opatření již s jistým efektem.

Problém však nastává u liniových biotechnických opatření, která ovlivňují povrchový odtok jinak, než opatření plošná. Jedná se zejména o př́kopy a průlehy, které soustřed'ují povrchový odtok a podle funkce odvádí nebo zadržují vodu, popř. vodu převádí do vedlejšího povodí. Zachytit tyto funkce $\checkmark$ hydrologickém modelu HEC-HMS je složitější. Podle prováděných rešerší (např. Kovář a kol. [9]) bývá schematizace liniových opatření nejčastěji řešena také změnou čísla CN, tedy se do modelu promítne jen např. zatravnění nebo jiná změna povrchu u daného opatření. Záměrem dalšího výzkumného řešení dané problematiky je propojení hydraulického modelu HEC-RAS (Hydrologic Engineering Center's River Analysis System) [1] a hydraulického modelu HEC-HMS.

Tabulka 2. Počty a délky liniových ochranných opatření v zájmovém povodí Table 2. Quantity and lengths of the line erosion control measures in the basin

\begin{tabular}{lcc} 
Typ opatření & Počet [ks] & Délka [m] \\
\hline zasakovací mez & 58 & 27528 \\
\hline stabilizace dráhy odtoku & 40 & 69219 \\
\hline zasakovací příkop & 1 & 533 \\
\hline zasakovací pás & 113 & 13410 \\
\hline Celkem & $\mathbf{2 1 2}$ & $\mathbf{1 1 0 6 9 0}$
\end{tabular}




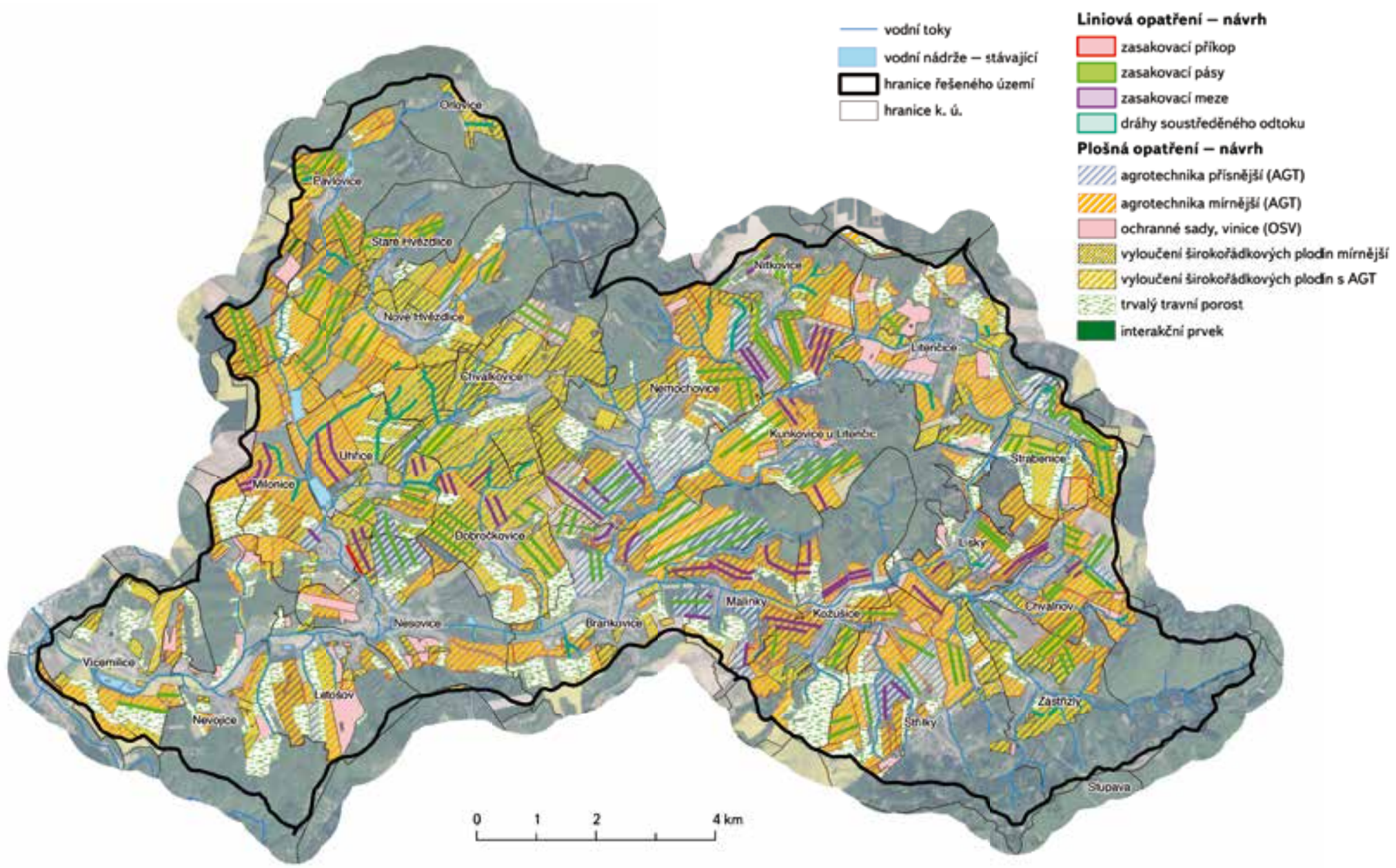

Obr. 4. Návrh plošných protierozních opatření v zájmovém povodí

Fig. 4. Design of erosion control measures

Tabulka 3. Vliv navrhovaných opatření na velikost kulminačních prütoků a objemy povrchového odtoku Table 3. Influence of designed measures on peak flow $\left(Q_{k u}\right)$ and runoff volume $(W)$

\begin{tabular}{lllccc}
\multirow{2}{*}{ Epizoda } & Profil & \multicolumn{3}{c}{ Bez opatření } & \multicolumn{2}{c}{ Návrhy opatření } \\
\cline { 2 - 5 } E1 & $\mathbf{W}\left[\mathrm{m}^{3}\right]$ & $\mathbf{Q}_{\mathrm{kul}}\left[\mathrm{m}^{3} / \mathrm{s}\right]$ & $\mathbf{W}\left[\mathrm{m}^{3}\right]$ & $\mathbf{Q}_{\mathrm{kul}}\left[\mathrm{m}^{3} / \mathrm{s}\right]$ \\
\hline \multirow{2}{*}{ E2 } & Brankovice & 501900 & 4,4128 & 280200 & 4,2027 \\
\cline { 2 - 6 } & Bučovice & 559400 & 4,9493 & 494900 & 4,7123 \\
\hline \multirow{2}{*}{ E3 } & Brankovice & 172500 & 4,1268 & 167600 & 3,9798 \\
\hline \multirow{2}{*}{ E4 } & Bučovice & 295000 & 5,6225 & 279400 & 5,325 \\
\cline { 2 - 6 } & Brankovice & 682300 & 7,548 & 586100 & 6,3011 \\
\hline & Bučovice & 1262800 & 12,2332 & 1058600 & 9,9781 \\
\cline { 2 - 6 } & Bučovice & 500300 & 11,5115 & 426100 & 9,6654 \\
\end{tabular}




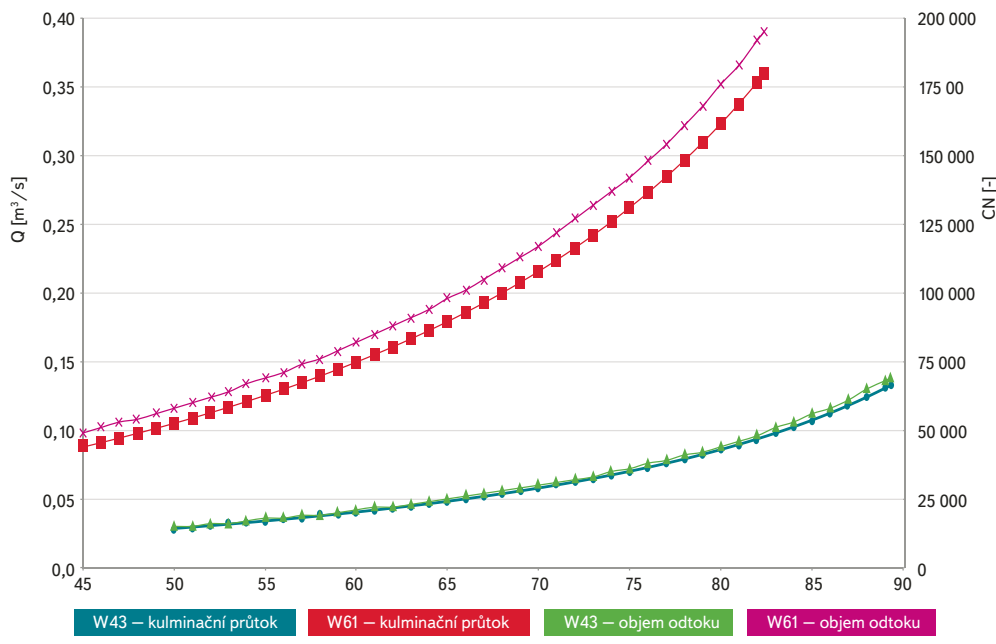

Obr. 5. Graf závislosti změny čísla CN na kulminačním průtoku a objemu odtoku Fig. 5. Graph of CN number, peak flow (blue and red) and runoff volume (green and purple)

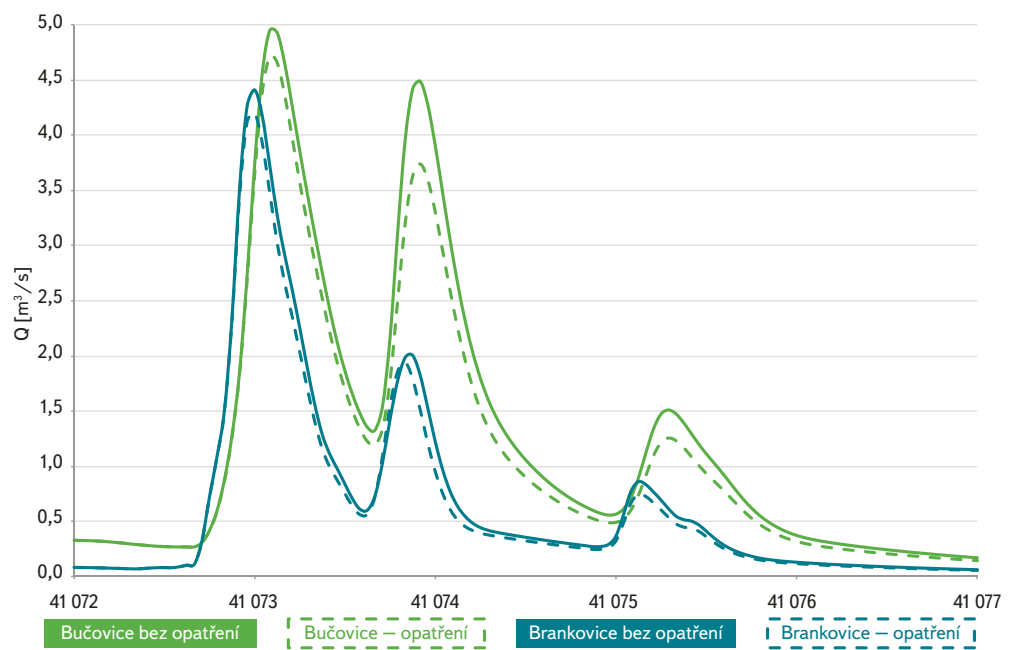

Obr. 6. Porovnání hydrogramů pro epizodu E1 ve dvou sledovaných profilech Fig. 6. Comparsion of hydrographs in two profiles (flood episode E1)

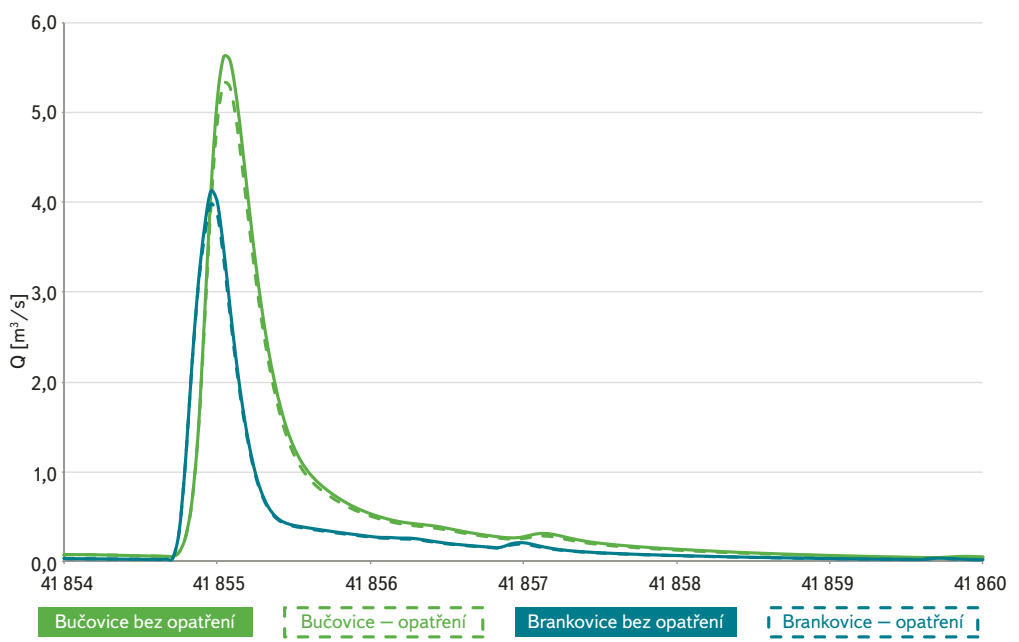

Obr. 7. Porovnání hydrogramů pro epizodu E2 ve dvou sledovaných profilech

Fig. 7. Comparsion of hydrographs in two profiles (flood episode E2)

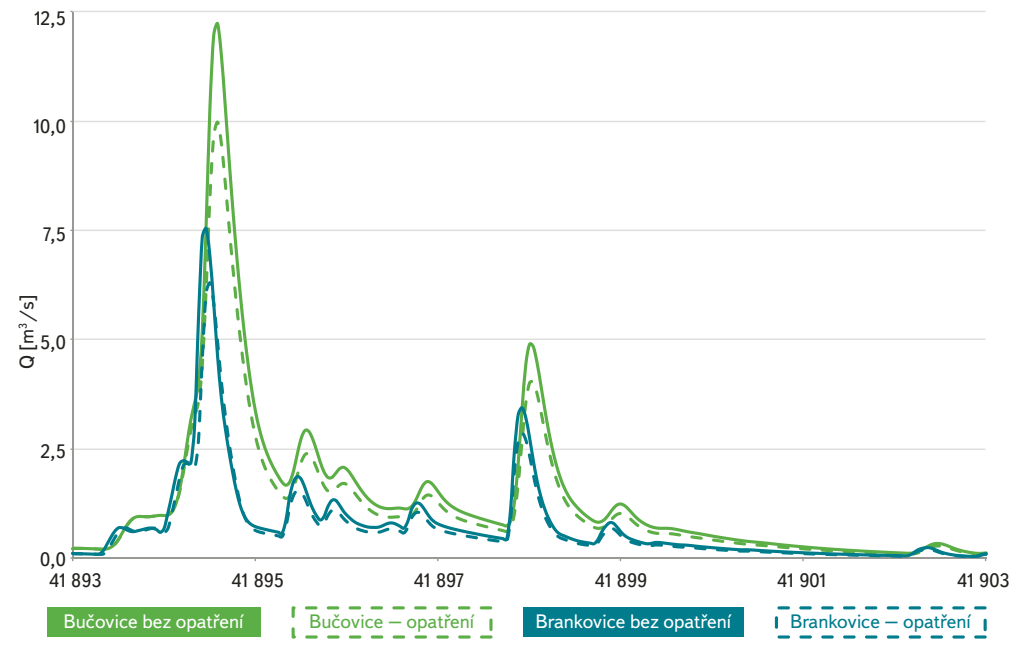

Obr. 8. Porovnání hydrogramů pro epizodu E3 ve dvou sledovaných profilech

Fig. 8. Comparsion of hydrographs in two profiles (flood episode E3)

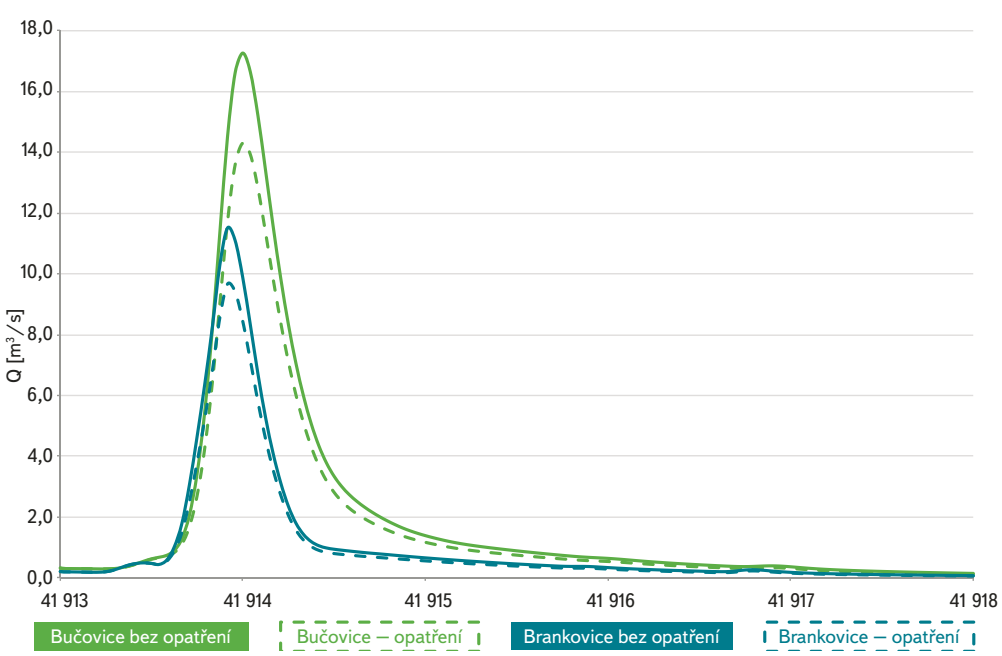

Obr. 9. Porovnání hydrogramů pro epizodu E4 ve dvou sledovaných profilech

Fig. 9. Comparsion of hydrographs in two profiles (flood episode E4)

$\checkmark$ modelech Ize schematizovat príkopy či průlehy jako samostatné úseky vodních tokủ, bude tak možné co nejpřesnější vystihnutí proudění v otevřeném korytě průlehu či př́kopu. Oba programy využívaji pro výpočet proudění v otevřeném korytě $v$ rámci zvolených metod stejné principy výpočtu. Tyto výpočty jsou založeny na Saint Venantovy rovnici, tedy kombinaci rovnice kontinuity a větě o hybnosti [1].

\section{ZÁVĚR}

Stanovení vlivu a efektivnosti ochranných opatření v ploše povodí je aktuální problematika, která nemá sjednocené metodické řešení. Přitom efektivita jednotlivých opatření by měla být jedním z hlavních parametrů pro posouzení vhodnosti a ekonomické výhodnosti. Dosavadní praxe navrhování ochranných opatření však obvykle nezahrnuje vyhodnocení ekonomické efektivnosti návrhu a z těchto důvodů často dochází k prosazování takových řešení ochrany území, která nejsou efektivní. Z tohoto zjištění vyplývá potřeba zpracovat metodiku pro hodnocení technicko-ekonomické účinnosti prvků protipovodňové a protierozní ochrany a následně ji implementovat do metodických postupů pro navrhování ochranných opatření v povodí. Negativní finanční 
a ekonomická návratnost opatření často pak vede k tomu, že se zemědělci jako uživatelé zemědělské půdy, popř. její vlastníci zdráhají zavádět protierozní opatrení bez patřičných náhrad.

Jedním z vhodných nástrojů pro hodnocení vlivů opatření na rozsáhlejších územích mohou být právě hydrologické srážko-odtokové modely, které dokáží vystihnout nejen změny kulminačních průtoků, posuny kulminací či změny v objemu povrchového odtoku, tedy veličiny, které jsou ochrannými opatřeními cíleně snižovány, ale i další parametry podle zvoleného modelu a softwaru. Zobrazení jednotlivých ochranných opatření však v mnoha modelech není jednoduché a např. v HEC-HMS Ize samostatně řešit pouze vodní nádrže. Naším cílem je tedy dále rozvíjet schematizaci a promítání jednotlivých opatrení do srážko-odtokového modelu tak, aby jejich vliv na sledované veličiny co nejvíce odpovídal reálnému stavu za použití výše zmíněných metod.

\section{Poděkování}

Př́spěvek vznikl za podpory projektu QJ1520268 „Nové postupy optimalizace systémů integrované ochrany území v kontextu jejich ekonomické udržitelnosti" řešeného $\checkmark$ rámci programu KUS Ministerstva zemědělství ČR.

\section{Literatura}

[1] HEC - Hydrologic Engineering Center. US Army Corps of Engineers [online]. 2010 [cit. 2018-02-13]. Dostupné z: http://www.hec.usace.army.mil/

[2] BANKS, J. Principles of Simulation. In: BANKS, J., (ed.) Handbook of simulation: Principles, Methodology, Advances, Applications, and Practice. John Wiley \& Sons, Inc., New York, 1998, s, 547-570. ISBN 0-471-13403-1.

[3] ČHMÚ - Hlásná a předpovědní služba [online]. 2018 [cit. 2018-04-04]. Dostupné z: http://hydro. chmi.cz/hpps/hpps_bklist.php

[4] ŠERCL, P. Vliv Fyzicko-geografických faktorů na charakteristiky teoretických návrhových povodñových vin. Praha, 2009. ISBN 978-80-86690-62-9.

[5] FELDMAN, A.D. (ed.). Hydrologic Modeling System HEC-HMS Technical Reference Manual. Washington: US Army Corps of Engineers, 2000.149 s. Dostupnýz www: http://www.hec.usace.army.mil/software/ hec-hms/documentation.html

[6] JENÍČEK, M. Modelování prüběhu extrémnich povodni v kontextu krajinných změn a integrované protipovodňové ochrany. Praha, 2009

[7] FELTL, J. Posouzení efektivity protipovodňové a protierozni ochrany malých povodí. Disertační práce. Brno: Vysoké učení technické v Brně, Fakulta stavební, Ústav vodního hospodářství krajiny, 2017. s. 26.

[8] STROUHAL, L. Kvantifikace vlivu liniových opatřeni na povodňové odtoky. Disertační práce. Praha: České vysoké učení technické $\vee$ Praze, Fakulta stavební, Katedra hydromeliorací a krajinného inženýrství, 2016. s. 77.

[9]KKOVÁR̆ P. a kol. Certifikovaná metodika optimalizace vodního režimu krajiny ke snižováni dopadů hydrologických extrémů, Praha: Katedra biotechnických úprav krajiny, Fakulta životního prostředí na Ceské zemědělské univerzitě v Praze, 2015, s. 36-42.

\section{Autoři}

Ing. Kamila Osičková

凶kamila.osickova@vuv.cz

Ing. Jana Uhrová, Ph.D.

凶jana.uhrova@vuv.cz

Výzkumný ústav vodohospodářský T. G. Masaryka, v. v. i., pobočka Brno

Příspěvek prošel lektorským řízením.

\section{EFFECTIVENESS ASSESSMENT OF THE DESIGNED MEASURES IN THE BASIN}

\section{OSICKOVA, K.; UHROVA, J.}

TGM Water Research Institute, p. r. i., Brno Branch

Keywords: Litavy basin - precipitaion-runoff model hydrological model - schematization - area erosion control measures - line erosion control measures - HEC-HMS

This article describes part of results of the project "QJ1520268 The new procedures of optimization systems integrated protection area in the context of their economic sustainability". The aim is effectiveness assessment of the designed measures in the Litava basin in hydrological model created in software HEC-HMS (Hydrology Engineering center - Hydrologic modeling system) [1]. For computing hydrologic loss and flood transformation was used SCS $\mathrm{CN}$ method. Designing of the measures affected schematization of the basin (fig. 1) and for flowless measures was computed retention capacity. The east part of Litava basin (area $136.85 \mathrm{~km}^{2}$ ) was chosen for morphological fragmentation, large agricultural use and many locations threatened by flash floods. This article also describes the creation of runoff model in HEC-HMS, including calibration (fig. 3), verification and simulation of the designed land use with line measures in the model. There are only two flow measurements in Litava basin in Brankovice and Rychmanov, so the hydrological model was created for large part of the Litava basin and next the priority part was calculated. In the priority part is about $59.38 \%$ agricultural used land and about $56.72 \%$ is fertile ground. The area erosion control measures were designed on the $93.91 \%$ of the fertile ground. Localization and design of erosion control measures is shown on fig. 4, types, areas and numbers of all measures are shown in table 1 and table 2 . The most used method to schematization of the measures to the precipitaion-runoff model is projection to CN number. Graph of CN number, peak flow and runoff volume is shown on figure 5. We want to achieve by further research better schematization of the measures in the model. The flowless measures could be inserted to HEC-HMS as component "reservoir" as infinitely small tank without functional objects and drainage measures could be inserted to the model as reaches of the river. This would be connected with hydraulic model HEC-RAS to project hydraulic flowing in the reach. On figure 6-9 is shown comparsion of hydrographs in two profiles for 4 real flood episodes with and without the measures. The runoff volume was reduced by $5.3-16.3 \%$ and the peak flow was reduced by $4.8-18.4 \%$. So the effectiveness assessment of the designed measures in the basin is not insignificant. 